\title{
Intrapreneurship Awareness Development for East Manufacturing Industries Employees in Thailand
}

\author{
Miss. Tugsina Pradit \\ Ph.D. Candidate Student of Business Management, \\ Graduated School, Suan Dusit Rajabhat University. \\ Ass. Prof. Dr. Nattaphan Kecharananta \\ Major Advisor, Business Management, \\ Graduated School, Suan Dusit Rajabhat University.
}

Doi: 10.5901/mjss.2013.v4n4p263

\begin{abstract}
This study is a mixed method research with qualitative research and quantitative. The qualitative was conducted by using InDepth Interview 6 key informants from governmental sector and 12 key informants from private sector. The quantitative was survey research with workers in East Manufacturing Industries in Thailand. The result of qualitative research revealed that the intrapreneurship awareness development had three components including human capital in terms of worker capital and administrator capital and acceptance and perception of outsider. The results of survey research was found that the support factors to be intrapreneurship awareness development correlated to intrapreneurship awareness development in terms of work appreciation and satisfaction with statistically significant at level of 0.05. Considering on each factors, it revealed that Management and Organization Motivation was the highest correlation with 0.663 and subsequences were Personal Competency, Transparency, Openness and Publicity, Organization Development, Working Place Environment, Innovation Motivation, and Personal Motivation with 0.661, 0.443, 0.431, 0.379, 0.334 and 0.271 respectively. Moreover, the support factors to be intrapreneurship awareness development correlated to intrapreneurship awareness development in terms of work appreciation and satisfaction with statistically significant at level of 0.05. Considering on each factors, it revealed that Management and Organization Motivation was the highest correlation with 0.594 and subsequences were Personal Competency, Transparency, Openness and Publicity, Innovation Motivation, Organization Development, Working Place Environment, and Personal Motivation with $0.585,0.464,0.431,0.344,0.317$ and 0.334 respectively.
\end{abstract}

Keywords: Intrapreneurship Awareness Development / East Manufacturing Industries Employees / Thailand

\section{Introduction}

The guideline of human resource development that Chayasriwong (Permanent secretary of Ministry of Labor of Thailand) mentioned on the policy of labor force development that Thailand needs to urgently develop skill labor to meet universal standard for skill labor that is congruent to competency for career part in order to support for economic structural adjustment inside country and to prepare the readiness of Thai labor force for Asian regional market and to be Asian Community in 2015. Therefore, within the context of Ministry of Labor, it must to take this responsibility (Chayasriwong, 2011). Libor is power of production and is the important factor to make product in economic system. Power of labor is a hidden in every product, therefore, the security, progress and good life quality of labor is still the duty of Ministry of Labor to look after them in both inside system and outside system to have to do, earn income, and life safety to be able to stand in society.

Pushing Thailand to be a center of car production and opening free trade area are important and essential issues that Thai small and middle entrepreneurs of car spare parts must adjust themselves to be able to compete with producers of other countries by improving the higher standard of production to pertinent with universal standard and demands of car production companies that these standards. Currently, car production companies set rather high standard for car spare part. This causes the automobile car spare part producers must to develop different features in all aspects of personal, product quality, technology and production standard in order to raise themselves to be accepted from car production companies both inside country and outside the country. Therefore, Thai entrepreneur need to develop for production standards to be more qualified product. Simultaneously, they are able to decrease capital as important implementation 
together with research and development. This will make them to be able to compete in global market with other countries in the future (Thailand Board of Investment, 2012).

Considering on the cause of labor lacking, it discovered that it lacks of skill labor in specific vocation with highest level with 26.1 percents. Subsequences was labor with inadequate basic knowledge in required position and labor had problem on rate of employment with 23.3 percents and 22.6 percents, inexperienced labor with 16.4 percents. Inappropriate personality and unskilled language, and lack of information technological skill were $9.1,2.2$, and 0.3 respectively.

With issue of lack of skilled labor is a component of human resource management, the business owner needs to search way or technique of new guideline of administration by searching different activities to promote worker to have entrepreneurship awareness or it was accepted as innovation of knowledge development and creative thinking to assist the organization to be able to develop product, service and work process to be high efficiency. Together with present current on entrepreneurship, was interesting increasingly and continuously. Therefore in the modern organization, human resource management is a mechanism to drive organization to meet the excellent business profit with worker awareness development inside organization (Intrapreneur) (Pinchot, 1985; Lumpkin, and Dess, 1996; Antoncic and Hisrich, 2001; Amo, 2010).

Good awareness raising of worker or creation of intrapreneurship for worker is an essential issue for organization. Administrators must regard to good consciousness cultivation to promote worker to practice with efficiency and to have target. Output of work would be highest quality. Moreover, the good conscious worker would have good consciousness to look after resources and properties of company with feeling as owner, therefore the managers must be patient, caution, and skillful to train and teach to be able to work effectively and they must monitor the worker after they delegated responsibility to work already and clarity, therefore they must examine the progress of work. This will stimulate worker to have creative thinking and work responsibility to have work result highest efficiency and effectiveness. Finally, organization will enter to effective organization (Chatkaew, 2010; Pinchot, 1985, ; Menzel, et al., 2006; Thiengkamol, 2007; Sharma, and Chrisman, 1999).

The worker with good consciousness in work practice, the benefit that organization received is decreased burden of control, therefore the worker would have initiative idea in working. The organization would have good trained worker and high competency to develop organization successfully. Therefore, human resource development to have high potential and efficiency are important parts and it would be a guideline for administrator to know what to do and how to make the worker to have feeling as entrepreneur. This is an interesting issue to be conducted since there is no clear conclusion to explain about components and influences of intrepreneurship to affect the result of organization implementation. Additionally, the related literatures with entrepreneur in Thailand is still very few (Lumpkin, and Dess, 1996; Antoncic and Hisrich, 2001; Amo, 2010; Dasgupta and Bhulla, 2011; Menzel, et al., 2006). Therefore, it is very important and essential to research on titled "Intrapreneurship

awareness development for east manufacturing industries employees in Thailand" with objective of requiring the private and governmental sector related production industry to develop the worker or labor of organization to have consciousness of intrapreneurship and together with recommendation and guideline of administration of governmental sector to promote worker in production industry to accomplish problem solving in accordance with academic principle for integrative and sustainable administration.

\section{Literature}

Eastern region of Thailand has important role for country development and in 2005 this region had Gross Regional Product (GRP) as send order after Bangkok and its vicinity. This resulted from the governmental policy in Eastern regional development as center of new economy and to be an area of main industry and export industry of country to support the extension of economic activities. Moreover, Eastern region still has another essential role of agriculture in terms of rice farming, fruit gardening and other perennial plants and includes the tourism site for both national and international levels. Additionally, it is also the commercial doors that connects to other countries in Indochina groups with developed network of infrastructural service in terms of roads, trains, deep water harbor, and airport to connect to international and to be able to support in all aspects of city, economic, and tourism development incessantly (National Economic Development Board Office of the Prime Minister, 2007).

With policy and these economic growths, there is an increasing investments and labor employment. It is obviously seen that there is area extension for construction of industrial estates and factories in area of eastern regional covering Rayong Province, Chonburi Province, and Chachaengsao Province. As it can be seen from some industrial estate extension such as Pin Thong Industrial Estate has extended increasingly, therefore this industrial estate has the 
investment from different investor for numerous industries such automobile industry and electronic industry for instances. Furthermore, governmental sector has policy to put up Thai automobile industry as strategic industry of country to step on center of car production in the region or Detroit of Asia by Ministry of Industry to make automobile industrial development and increased capability of competition and competency development to be readiness for center of car production (National Economic Development Board Office of the Prime Minister, 2007; Asasappakij, 2013).

Beside, industry in eastern region still receives the promotion and support from governmental sector in different facets as Hanhiran, inspector general of Ministry of Industry (2011) gave interview about the situation of investment in the eastern region that there is complete infrastructure and public assistance but it just lacks of support for extensions of city plan so it cannot extent the area and lack of skill labors and general labor in eastern regional industry in parts of automobile, electronic, and textile industries (World Bank, 2012a).

National Statistical Office had surveyed the requirement of labor demand and labor shortage in different industries in B.E. 2549 while it was classified according to type of industry, it was found that labor demand and labor lack of firm were textile and clothes industries with demand of 116,752 peoples and lack of 50,330 peoples. The electrical appliance production and electronic industries require 130,710 peoples and lack of 6,192 peoples. Automobile and spare part industries require 12,855 peoples and lack of 2.724 peoples (Dasgupta and Bhulla, 2011).

\section{Objective}

The research objectives were as followings:

1) To determine the Management and Organization Motivation, Personal Motivation, Transparency Openness and Publicity, Personal Competency, Working Place Environment, Innovation Motivation, and Organization Development affected to Intrapreneurship Awareness Development in Terms of Work Appreciation and Satisfaction.

2) To determine the Management and Organization Motivation, Personal Motivation, Transparency Openness and Publicity, Personal Competency, Working Place Environment, Innovation Motivation, and Organization Development affected to Intrapreneurship Awareness Development in Terms of Other Satisfactions.

\section{Methodology}

The research design was implemented in steps by step as followings:

1. The qualitative research was conducted with by using In-Depth Interview with 6 Key informants from governmental sector and 12 key informants from private sector (Thiengkamol, 2011a). The quantitative was survey research with workers in East Manufacturing Industries in Thailand. The content analysis was employed for qualitative research. Pearson correlation was used for survey data analysis.

2. The quantitative research was used for surveying the worker opinion on support factors and intrapreneurship awareness development. The purposive sampling was conducted for data collection from sample group of 382 workers from Amata Nakorn Industrial Estate in Eastern Region of Thailand. The questionnaire was used as tool for data collection. The reliability of Management and Organization Motivation, Personal Motivation, Transparency Openness and Publicity, Personal Competency, Working Place Environment, Innovation Motivation, Organization Development, Work Appreciation and Satisfaction, and Other Satisfactions in work, were $0.878,0.828,0.808,0.80,0.891,0.834,0.821,0.853$ and 0.844 .

\section{Results}

This study is a mixed method composed of qualitative and quantitative researches.

\subsection{Result of qualitative research}

The content analysis of 22 key informants of governmental and private sectors, it was revealed that the support factors affected to intrapreneurship awareness development of workers in East Manufacturing Industries in Thailand were Management and Organization Motivation, Personal Motivation, Transparency Openness and Publicity, Personal Competency, Working Place Environment, Innovation Motivation, and Organization Development, Work Appreciation and Satisfaction, and Other Satisfactions in work. 


\subsection{Result of quantitative research}

\subsubsection{Intrapreneurship Awareness Development in Terms of Work Appreciation and Satisfaction}

From survey research with workers in East Manufacturing Industries in Thailand, it was illustrated that the support factors in terms of Management and Organization Motivation, Personal Motivation, Transparency Openness and Publicity, Personal Competency, Working Place Environment, Innovation Motivation, and Organization Development affected to Intrapreneurship Awareness Development in Terms of Work Appreciation and Satisfaction with correlation of $r=0.663$, $0.271,0.443,0.611,0.379,0.334$, and 0.431 with statistically significant at level of 0.05 as presented in table 1 .

Table 1 Pearson Correlation between the Support Factors Affected Intrapreneurship Awareness Development in Terms of Work Appreciation and Satisfaction

\begin{tabular}{|l|c|}
\hline $\begin{array}{l}\text { Support Factors to be Intrapreneurship } \\
\text { Awareness Development }\end{array}$ & $\begin{array}{l}\text { Intrapreneurship Awareness Development } \\
\text { in Terms of Work Appreciation and Satisfaction }\end{array}$ \\
\hline Management and Organization Motivation & $r=0.663 *$ \\
\hline Personal Motivation & $r=0.271 *$ \\
\hline Transparency Openness and Publicity & $r=0.443 *$ \\
\hline Personal Competency & $r=0.611 *$ \\
\hline Working Place Environment & $r=0.379 *$ \\
\hline Innovation Motivation & $r=0.334 *$ \\
\hline Organization Development & $r=0.431 *$ \\
\hline
\end{tabular}

${ }^{*}$ Correlation at 0.05 level

From table 1, the support factors to be intrapreneurship awareness development correlated to intrapreneurship awareness development in terms of work appreciation and satisfaction with statistically significant at level of 0.05 . Considering on each factors, it revealed that Management and Organization Motivation was the highest correlation with 0.663 and subsequences were Personal Competency, Transparency, Openness and Publicity, Organization Development, Working Place Environment, Innovation Motivation, and Personal Motivation with 0.661, 0.443, 0.431, $0.379,0.334$ and 0.271 respectively.

\subsubsection{Intrapreneurship Awareness Development in Terms of Other Satisfactions}

From survey research with workers in East Manufacturing Industries in Thailand, it was illustrated that the support factors in terms Management and Organization Motivation, Personal Motivation, Transparency Openness and Publicity, Personal Competency, Working Place Environment, Innovation Motivation, and Organization Development affected to intrapreneurship awareness development in terms of other satisfactions with correlation of $r=0.594,0.0 .316,0.464,0.585$, $0.317,0.344$, and 0.431 with statistically significant at level of 0.05 as presented in table 2 .

Table 2 Pearson Correlation between the Support Factors Affected Intrapreneurship Awareness Development in Terms of Other Satisfactions

\begin{tabular}{|l|c|}
\hline $\begin{array}{l}\text { Support Factors to be Intrapreneurship } \\
\text { Awareness Development }\end{array}$ & $\begin{array}{l}\text { Intrapreneurship Awareness Development } \\
\text { in Terms of Other Satisfactions }\end{array}$ \\
\hline Management and Organization Motivation & $\mathrm{r}=0.594^{*}$ \\
\hline Personal Motivation & $\mathrm{r}=0.316^{*}$ \\
\hline Transparency Openness and Publicity & $\mathrm{r}=0.464^{*}$ \\
\hline Personal Competency & $\mathrm{r}=0.585^{*}$ \\
\hline Working Place Environment & $\mathrm{r}=0.317^{*}$ \\
\hline Innovation Motivation & $\mathrm{r}=0.344^{*}$ \\
\hline Organization Development & $\mathrm{r}=0.431^{*}$ \\
\hline
\end{tabular}

* Correlation at 0.05 level 
From table 2, the support factors to be intrapreneurship awareness development correlated to intrapreneurship awareness development in terms of work appreciation and satisfaction with statistically significant at level of 0.05 . Considering on each factors, it revealed that Management and Organization Motivation was the highest correlation with 0.594 and subsequences were Personal Competency, Transparency, Openness and Publicity, Innovation Motivation, Organization Development, Working Place Environment, and Personal Motivation with 0.585, 0.464, 0.431, 0.344, 0.317 and 0.334 respectively.

\section{Discussion}

This research is a mixed method research composed of qualitative research by Using In-Depth Interview to collect data from 6 key informants from governmental sector and 12 key informants from private sector who are involved in the East Manufacturing Industries in Thailand, it was revealed that the support factors affected to intrapreneurship awareness development of workers in East Manufacturing Industries in Thailand were Management and Organization Motivation, Personal Motivation, Transparency Openness and Publicity, Personal Competency, Working Place Environment, Innovation Motivation, Organization Development, Work Appreciation and Satisfaction, and Other Satisfactions in work. The Management and Organization Motivation was congruent concepts of Patarabunjerd, (2008) mentioned that the entrepreneur should have ability to motivate through management and organization motivation (Patarabunjerd, 2008). Transparency openness and publicity was also pertinent to concept of Thiengkamol, pointed out that the successful entrepreneur should manage organization with transparency, accountability and consensus oriented (Thiengkamol, 2007). Consequently, effective entrepreneur should be able to motivate for innovation creation. This characteristic is accordance with the concept of Miller about innovation creation (Miller, 1983; Pinchot, 1985) and in the line with the definition of entrepreneurial orientation that was given by Lumpkin and Dess (1996). However, personal motivation is an essential factor to support the intrapreneurship awareness development if the entrepreneur has high personal motivation; he or she would able to create like as Zuckerberg with good idea and high competency to search new management strategy to overcome any obstacle to accomplish effective organization operation (Zuckerberg, 2010; Chatkaew, 2010). Consequently, organization development, the entrepreneur is very important person as change agent of organization that was congruent to concept of Amo (2010) including entrepreneur is an essential person to create and build comfortable working place environment (Amo, 2010; Naveekarn,1993).

From survey research, the results illustrated that the support factors to be intrapreneurship awareness development of workers in East Manufacturing Industries in Thailand including Management and Organization Motivation, Personal Motivation, Transparency Openness and Publicity, Personal Competency, Working Place Environment, Innovation Motivation, Organization Development correlated to Work Appreciation and Satisfaction, and Other Satisfactions in Work with statistically significant at 0.05 level. Nevertheless, it be concluded that the supporting factors found from governmental and private key informants were congruent to the supporting factors to be intrapreneurship awareness development of workers in East Manufacturing Industries in Thailand from survey research. Additionally, these support factors to be intrapreneurship awareness development of workers are also correlated to Work Appreciation and Satisfaction, and Other Satisfactions in Work (Patarabunjerd, 2008; Thiengkamol, 2007; Miller, 1983; Pinchot, 1985; Lumpkin and Dess, 1996; Zuckerberg, 2010; Chatkaew, 2010; Amo, 2010; Naveekarn,1993). Therefore, the entrepreneurs in the eastern industrial region can use to inspire and motivate their worker to have intrapreneurship awareness in order to support and promote the more effectiveness and efficiency in working. Finally, their business would grow sustainably.

\section{References}

Amo, L. (2010). Fostering Intrapreneurship : The New Competitive Edge, Conference on Global Competition and Competitiveness of Indian Corporate, P. 149-156.

Antonic, B., \& Hisrich, R.D., (2001). Intrepreneurship: construct refinement and cross cultural validation. Journal of Business venturing. $16,495-527$.

Asasappakij, P. (2013). How Thailand can become the 'Detroit of Asia'. Retrieved from:http://www.nationmultimedia.com/business/HowThailand-can-become-the-Detroit-of-Asia-30179713.html

Chayasriwong, S. (2011). Labor Policy. Journal of Labour, 3 (3), 17.

Dasgupta, S and Bhulla, R.. (2011) Labour shortages - trades and policy implications for Thailand, unpublished document, International Labour Organization (ILO) Population Division of the Department of Economic and Social Affairs of the United Nations Secretariat. (2010). World Population Prospects: The 2010 Revision 
Lumpkin, G., and Dess, G. (1996). Clarifying the entrepreneurial oorientation construct and linking it to performance. Academy of Management Review, 21(1), 135-172.

Menzel, H,C., Kraus, R., Uljin, J. M. \& Weggerman, M.C.D.P. (2006). Developing Characteristics of an Intrapreneurship-Support Culture, Entrepreneurship Research and Education, 3rd European Summer University, Temper University, p. 25- 30.

Naveekarn, S. (1993). Administration. Bangkok: Dok Yha. Publishing.

Patarabunjerd, S. (2008). Factors leading the success of SMEs entrepreneur". Retrieved from: www. Attanakit.net.

Pinchot, G. (1985). Intrapreneuring: Why You Don't Have to Leave the Corporation to Become an Entrepreneur. New York: Harper \& Row.

Chatkaew, T. (2010). "Treasure at the end of horizon of Thai Entrepreneur". Journal MBA.

Sharma, P., and Chrisman, J.J. (1999), "Toward a reconciliation of the definitional issues in the field of corporate entrepreneurship", Entrepreneurship Theory and Practice, Vol. 23 No.3, pp.11-27

Thailand Board of Investment. (2012). Thailand: The Detroit of Asia. Retrieved from http://robyscar.wordpress.com/2012/08/14/thailandthe-detroit-of-asia/

The National Economic Development Board Office of the Prime Minister. (2007). The Tenth Economic and Social Development Plan (2007-2011). Retrieved from http://www.nesdb.go.th/Default.aspx?tabid=402

Thiengkamol, N. (2007). Globalization Administration. Bangkok: Saengchai Publishing.

Thiengkamol, N. (2011a). Holistically Integrative Research. (2nd Edition). Bangkok: Chulalongkorn Press.

World Bank. (2012a). Leading with Ideas: Skills for Growth and Equity in Thailand, Conference Edition, Seminar on Skill and Higher Education for Ideas-Led Growth with Equity in Thailand, February 20, 2012, Bangkok.

Zuckerberg, M. (2010). World's Largest Online Community. Join for Free \& Enjoy the Benefits! Retrieved from: http://www.biography.com/people/mark-zuckerberg-507402 